\title{
A szövegszerveződésre irányuló metapragmatikai reflexiók a tudomány szakszövegeiben*
}

1. Bevezetés. A tanulmány a kognitív szemantika (LANGACKER 1987, 2008; TOLCSVAI NAGY 2017b, 2017c) és a pragmatika mint szemléletmód (VERSCHUEREN 1999; TÁTRAI 2011, 2017) együttes érvényesítésével a tudáskonstruálást, illetve annak módját előtérbe helyezve a tudományos szakszövegeket a tudomány szakszövegeiként értelmezi, melyben a TUDÁS ${ }^{1}$ megosztása valósul meg, amit alapvetően a megosztásra irányuló reflexív attitüd jellemez. Az ekképp metadiskurzusoknak tekinthető szövegek meta összetevőjét helyezi elötérbe, és a metapragmatikai reflexiók lehetőségeit az irányulásuk alapján vizsgálja. Mindezen lehetőségek közül a szöveg szerveződésére irányulókra fókuszál. Egy tanulmánykötet (TOLCSVAI NAGY GÁBOR szerk., Szöveg és típus. Szövegtipológiai tanulmányok. Tinta Könyvkiadó, Budapest, 2006) szövegeinek kvalitatív elemzésével a diskurzusdeixis müveletét megvalósító nyelvi eszközök, továbbá a diskurzusjelölők működését elemzi, mindeközben a szöveg szerveződésére reflektáló nyelvi lehetőségek közötti hasonlóságokat és különbségeket a tudomány szakszövegeiben történő müködésük alapján értelmezi. Ez a vizsgálat a deixis müködésének árnyaltabb bemutatása céljából az MNSZ2 (v2.0.5) tudományos alkorpusz véletlen listájának elemzésével is kiegészül.

2. Tudáskonstruálás a tudomány szakszövegeiben. A tanulmány a szakszövegekben zajló tudásmegosztást előtérbe helyezve a tudományos szövegeket a tu d o má ny s zaks zöve ge i ként értelmezi. Ezen értelmezés látszólag leszúkíti magát az értelmezői keretet, de lehetőséget ad a szakszöveg és a szakszövegtípusok sajátosságainak leírásához, illetve e szövegek más szakszövegtípusokhoz való viszonyának a bemutatásához. A tudományos jelző lecserélése a nominális tudományra azzal jár, hogy elkülönülnek azon szövegek, melyek az adott beszédhelyzetben tudományosnak tekinthetők, de nem a tudomány diskurzustartományát (a fogalomra 1. TAAVITSAINEN-JUCKER 2010; KUNA 2016: 388-389; CSONTOS 2019a:155-156; vö. még RoELCKE 2002; KUNA-LuDÁNYI 2019) dolgozzák ki, illetve nem a tudomány befogadócsoportjának szólnak. Az elkülönítés viszont korántsem jelent elhatárolást: a tudomány szakszövegei és a nem a tudomány szakszövegei közötti átmeneti kategóriába számos olyan szöveg sorolható, melyek

* A tanulmány a Károli Gáspár Református Egyetem Bölcsészet- és Társadalomtudományi Kar 20633B800 számú Diskurzusjelölők nyelv- és műfajközi kutatása címü pályázatának támogatásával készült.

${ }^{1}$ Itt a TUDÁs 'a szakszöveg által rendezett és expliciten közölt ismeret'-et jeleníti meg. A tanulmány további részeiben az ekképp használt tudás-t minden esetben kiskapitális jelöli. Emellett kiskapitális jelöli a szakszöveg, illetve a szakszövegtípus további sematikus összetevőit is, valamint az egyéb fogalmi tartományokat.

Magyar Nyelv 117. 2021: 278-297. DOI: https://doi.org/10.18349/MagyarNyelv.2021.3.278 
a széles értelemben vett kontextuális körülményekhez igazodva vagy igazítva különböző mértékben jelenítik meg a SZAKTERÜLETI TUDÁS-t, figyelembe véve például a befogadók elvárásrendszerét a téma kidolgozási módjában. Így e szövegek a bennük érvényesített SZAKTERÜLETI TUDÁS mértéke és kidolgozottsági módja alapján fokozatiságot mutatnak. A tipikus beszédhelyzeteket tekintve a tudomány szakszövegei azon prototipikus szakszövegeket ölelik fel, melyekben a SZAKTERÜLETI TUDÁS, valamint annak megosztása zajlik egy olyan befogadócsoportra számítva, melynek elvárása e szövegekkel kapcsolatban szintén a SZAKTERÜLETI TUDÁS érvényre jutása. A SZAKTERÜLETI TUDÁS mértéke a befogadói csoporthoz és természetesen a különböző célokhoz igazítva kategóriákat alakít ki; a tudomány szakszövegei - a fokozatok mentén - érintkeznek olyan szakszövegekkel, melyekben a tudományosság mértéke alacsonyabb. A t u d o m á n y o s s á g tehát egy olyan dimenziójává válhat a szakszövegeknek, mely nem egy kategóriát jelöl ki, hanem több kategóriát jellemez.

Jelen munka amellett érvel, hogy a TÁRGY, a TUDÁs és konstruálása, a CÉL és a BEFOGADÓ közötti megjelenített viszonyból a tudományos szakszövegek fokozatokba rendeződő, nyitott kategóriát alkotnak, mely más szakszövegekkel a bennük érvényre jutó tudomány(osság) fokának érvényesülése által a tudomány szakszövegeivel érintkezhetnek, de prototipikus megvalósulásuk a tudomány szakszövegeit jelenti (vö. GRUBER et al. 2006: 26; DÉR 2019: 132-134). Ha a szövegeknek a csomópontba rendeződését vizsgáljuk, a tudomány szakszövegei - nyitott tartományként - külön kategóriát képeznek (vö. PARODI 2009: 484).

A tudomány szakszövegeiként értelmezett diskurzusok a TÁRGY-ra vonatkozó TUDÁs megosztásának módja miatt m e ta d i s k u rzu s oknak tekinthetők. Itt ugyanis a SZAKTERÜLETI TUDÁS egy nézőpontból történő konstruálása lép elötérbe: nem(csak) arról van szó, hogy a TÁRGY-hoz köthető alapvető TUDÁs kerül átadásra, hanem sokkal inkább a TÁRGY-gyal kapcsolatos TUDÁs-nak a beszélő perspektívájából történő értelmezése és annak megosztása zajlik. Itt szükséges a m e g o s ztá s múveletét külön hangsúlyozni, illetve folyamatjellegét elötérbe helyezni. Ezen szakszövegeknél ugyanis dominánsan érvényesül az a folyamat, amelyet az átadás és a megosztás közötti jelentésbeli különbség képes reprezentálni. A TUDÁs á t a dás a „olyan müveletre utal, amely csak a továbbítás egyirányú kommunikációelméleti modelljében müködik. Éspedig úgy, mint valami már birtokunkba vett meglevőnek a másokhoz való eljuttatása" (KULCSÁR SZABÓ 2017: 14). Ezen szövegek esetében a TUDÁs me g o sztá s a dominánsan nem ér véget az átadás mủveleténél, hanem a befogadónak lehetősége van arra, hogy a megosztott jelentéstartalmakra reflektáljon: a megértési és értelmezési folyamata során elfogadja vagy kritikával illesse a szöveg által megosztott TUDÁs-t. A szövegek jellemzően ezt is várják el a befogadójuktól. A TUDÁs konstruálása során a szövegalkotó a metareflexiói által kísért tudásmegosztással készteti befogadóját arra az együttgondolkodásra, melynek céljából e szövegeket létrehozza. E szövegekkel kapcsolatban tehát azt érdemes hangsúlyozni, hogy valódi diszkurzivitásukat azáltal nyerik el, hogy a szövegalkotó és a befogadója közötti közös jelentésképzési múveletnek hatékony megtételére alapoznak, lehetőséget adva mind az alkotás, mind a befogadás folyamatában a szöveg által implikált, 
elvárt vagy inkább lehetővé tett metadiskurzusok és metareflexiók megtételére (vö. KULCSÁR SZABÓ 2017: 13-36; TOLCSVAI NAGY 2017a: 39-46, 56-58).

\section{A metapragmatikai tudatosság és érvényesülése a tudomány szakszö-} vegeiben. A metapragmatikai tudatosság (VERSCHUEREN 1999: 187-198; TÁTRAI 2011: 119-125, 2017: 1046-1053) a diskurzus résztvevőinek reflexív viszonyulását jelöli a nyelvi tevékenységhez, illetve a nyelvi tevékenység keretében zajló dinamikus jelentésképzéshez. Ezen reflexív tevékenység egyaránt érintheti az adott diskurzus szerveződését, a diskurzus során kifejtésre kerülő jelentések tartalmát és módját, a konstruálás folyamatát. A megnyilatkozó saját diskurzusát éppúgy reflexió tárgyává teheti, mint a mástól származó diskurzusokat, de emellett a befogadói tevékenységhez is füzhet reflexiókat. A metapragmatikai tudatosság nyelvi kifejezései által a figyelem a diskurzus valamely összetevőjére, illetve annak folyamatára irányul. Az aktuális megnyilatkozónak a metapragmatikai jelzései a közös figyelmi jelenetre vagy annak létrehozására, illetve a feldolgozás folyamatára irányulhatnak, a figyelem előterébe állítva a diskurzus valamely összetevőjét vagy annak szerveződését. A metapragmatikai tudatosság a kognitív pragmatika felfogása által kínált tágabb értelmezésben egyaránt jelenti a metapragmatikai és az azzal fogalmilag rokon metanyelvi reflexiókat, de ide tartozhatnak azon metanyelvi és egyéb utalások is, amelyek a nyelvhasználatra és a közös figyelmi jelenetben zajló jelentésképzésre reflektálnak. Így egyaránt jelentheti a) a nyelvi tevékenységre, a mondás aktusára; b) a megértésre és a közös jelentésképzésre; c) a figyelem irányulására, illetve irányítására; d) a tudásra, a gondolkodásra, illetve annak folyamatára; e) a diskurzusra, a diskurzus szerveződésére, folyamatára és nyelvi megformáltságára történő reflektálást (vö. KUNA-HÁMORI 2019: 215-240; LACZKÓ 2019: 247-248). Mindezen összetevők egyaránt felölelik az aktuális megnyilatkozónak a saját nyelvi tevékenységéhez füződő vagy más személy nyelvi tevékenységéhez kapcsolódó reflexióit. Ezen metapragmatikai jelzések a közlés vagy a közöltek konstruálási folyamatában a szubjektivizáció (SANDERS-SPOOREN 1997: 95; TOLCSVAI NAGY 2017c: 306-309) eszközévé válhatnak, hiszen az aktuális megnyilatkozó ezen reflexiók által saját tevékenységéhez vagy a közöltekhez való szubjektív viszonyulását teheti jelöltté.

A metapragmatikai tudatosság mértéke, így a metapragmatikai jelzések jelenléte, terjedelme, nyelvi formái eltérők lehetnek a különböző diskurzusokban, illetve a diskurzusokra, valamint az azokban funkcionáló részekre is jellemzővé válhatnak. A kidolgozottságának mértéke fokozatiságot mutat (VERSCHUEREN 1999: 188), a reflexiókat kifejező nyelvi eszközök különböző szerkezetủ terjedelemben valósulhatnak meg, a kifejtettebb metanyelvi reflexióktól kezdve (pl. kívánja bemutatni, [úgy/azt] gondolom) a rövidebb kifejezéseken keresztül (pontosabban, összegezve) egészen az igemódhasználatig vagy a -hat/-het képző alkalmazásáig. Továbbá - mint már a példákból is látható - a diskurzusjelölők (DÉR 2009: 293-303) is lehetnek a metapragmatikai tudatosság jelölőeszközei.

A tudomány szakszöve ge i nek metadiskurzusként történő értelmezése már előfeltételezi azon folyamatokat, melyek a metapragmatikai tudatosság kérdéskörének vizsgálatát, illetve e vizsgálat előtérbe helyezését indokolják. A meta- 
diskurzus értelmezői keret azt állítja elötérbe, hogy ezekben a szövegekben nem csupán a TUDÁS átadása zajlik, hanem annak egy nézőpontból, szemléletmódból, elméleti keretből való értelmezett reprezentálása, illetve egy kutatási folyamathoz kapcsolódó megosztása. Ezen tudásmegosztást szükségszerúen jellemeznek azon reflexiók, melyek a TUDÁs hozzáférhetővé tételét meghatározzák.

A tudomány szakszövegeiben a metapragmatikai reflexiók a) a szöveg szervezödésére (a következőkben, itt, összegezve), b) a szövegalkotó nyelvi tevékenységére, a szövegalkotói folyamatra, azon belül a mondásra, a tudásra, a gondolkodásra (hangsúlyozom, gondolom, hiszem), továbbá c) a közös jelentésképzés folyamatára, ide számítva a figyelem irányulását is (értve ezen, ez azt jelenti, megfigyelhetö), d) a szövegalkotó és a befogadó közötti interakcióra (láthatjuk, mint látható), e) az elmondottak értékelésére (nyilvánvalóan, valószinüleg, talán) és f) a szövegbe ágyazódó, mástól származó diskurzusokra vagy azoknak említésére irányulnak. A felsorolt metapragmatikai lehetöségek mellett e szövegekben még egy, a metapragmatikai tudatosság jelenségébe sorolható reflexiótípus figyelhető meg: g) a nem nyelvi jellegü tevékenységre, illetve a nyelvi és a nem nyelvi tevékenység közötti átmeneti kategóriába sorolható tevékenységre irányulókra, ezen belül egyfelől a szövegszerveződésre (bemutatom, elemzem), másfelől a megosztani kívánt TUDÁS-hoz kapcsolódó tevékenységekre (vizsgálom, törlöm, elvetem) irányuló reflexiók. Ezek olyan nem (tisztán) nyelvi tevékenységet tesznek elérhetővé, melyek a tudomány szakszövegeinek közös figyelmi jelenetében a TUDÁs kidolgozási módjához, ezáltal hozzáférhetővé tételéhez járulnak hozzá, az interszubjektív feldolgozás és az arra való nyelvi reflektálás miatt sorolhatók a metapragmatikai tudatosság körébe. E reflexiók arra is ráirányíthatják a figyelmet, hogy a tudomány szakszövegei a narratívákhoz hasonlóan müködnek: ebben a keretben elkülöníthető egy olyan szólam, mely a kutatás leírását, az értelmezői keretet, a vizsgálat folyamatát tartalmazza (narráció), illetve egy olyan, mely maga a TUDÁs és annak kifejtése (történet). A „narráció” elemei itt a „történet” megértéséhez és értelmezéséhez jelölik ki az útvonalat, keretezve, specifikálva a TUDÁs-t és annak összetevöit, ezeknek nem nyelvi összetevői - az esetükben megfigyelhető metaforikus jelentésképzés miatt a MONDÁS aktusára, a téma, a „történet” kifejtésére való reflexióként értelmezhetők. E reflexiók a metapragmatikai tudatosság határeseteinek is tekinthetők (1. KUNAHÁMORI 2019: 229), de egyfelöl azért, mert jelenlétük a tudomány szakszövegeiben dominánssá válik, másfelől azért, mert a TUDÁs konstruálásának folyamatában aktív részt vállalnak, ezek a szöveg szerveződését, illetve a szövegalkotói tevékenységet elvégző metapragmatikai reflexiók közötti átmeneti kategóriába sorolhatók.

A tudomány szakszövegeiben a felsorolt metapragmatikai reflexiók a TUDÁS konstruálási folyamatára reflektálnak, azt teszik feldolgozhatóvá és elérhetővé, amellett, hogy a befogadó számára kijelölnek egy megértési és értelmezési útvonalat is. Ezáltal ezek a reflexiók e szakszövegekben a megosztani kívánt TUDÁS hozzáférhetővé tételéhez járulnak nagyban hozzá.

4. A szöveg szerveződésére irányuló metapragmatikai jelzések. A szövegszerveződésre irányuló metapragmatikai jelzések egyfelőla a i s k u r z u s d e i x i s , másfelől a dis k ur z u s j e lölők kérdéskörét foglalja magában. 
A d e ix i s - röviden összegezve - a társas-kognitív keretben olyan nyelvi müveletnek tekinthető, amely a diskurzus értelmezésébe bevonja a résztvevők fizikai és társas világát. Azon kontextuális ismeretek jönnek ezáltal mozgásba, amelyek a beszédesemény tér- és időbeli, valamint szociokulturális viszonyainak feldolgozásából származnak (LEVINSON 2004; LACZKÓ 2008, 2010; TÁTRAI 2011: 126-150, 2017: 953-980). A közvetett interakcióval jellemezhető - a tanulmány alapját képező - írott nyelvi szövegekben a deixis megvalósulása szimbolikussá válhat. A deiktikus nyelvi kifejezések szimbolikussága abban mutatkozik meg, hogy a beszédhelyzet résztvevőinek nincs lehetőségük arra, hogy a megnyilatkozás során annak fizikai körülményeiről közvetlen, érzékszervi tapasztalatot szerezzenek. A deixis szimbolikus megvalósulása elsősorban a térbeli referenciák azonosítását érinti, e kontextusfüggő viszonyítási pont feldolgozásához az írott nyelvi diskurzusok során nem használhatók fel a vizuális reprezentációk, illetve a gesztushasználat. Szimbolikusnak tekinthetó a diskurzus de ix is (LEVINSON 1983: 54, 85-94; MARMARIDOU 2000: 93-96; TÁTRAI 2017: 974-976; LACZKÓ 2019), mely egyfelől A DISKURZUS TÉR, valamint A DISKURZUS IDŐ metaforát kihasználva a diskurzusra, annak egy részletére, nyelvi megformáltságára, illetve a diskurzus szerveződésére való rámutatást végzi el. A diskurzusdeixis tehát nem a szövegvilág résztvevőinek fizikai és társas világát vonja be a szöveg értelmezésébe, hanem magát a diskurzust, illetve annak szerveződését teszi reflexió tárgyává; általa a diskurzusban való kontextusfüggő tájékozódás valósul meg. Mindezek alapján a diskurzusdeixis a metapragmatikai tudatosság eszközének tekinthető, e deixisfajtát megvalósító deiktikus nyelvi elemek metapragmatikai reflexiókat végeznek el (vö. TÁTRAI 2017: 976; LACZKÓ 2019: 248-249).

A diskurzusdeixis jellegzetes kifejezőeszközei egyebek közt a mutató névmások, melyek közül a magas hangrendüek jellemzően a diskurzusdeixis mủveletének megvalósításában, a mély hangrendủek pedig tipikusan a koreferencián alapuló kapcsolat jelölésében, azon belül az anaforikus viszony megjelenítésében müködnek közre (vö. LACZKÓ-TÁTRAI 2012: 231-257; LACZKÓ 2019: 242). Emellett használatuk során az is kiemelkedővé válhat, hogy a palatálisok a beszélöhöz viszonyított metaforikus 'közelséget', a velárisok a tőle való 'távolságot' tudják megvalósítani. A két funkciót összekapcsolva az mondható el, hogy a palatális mutató névmások a kontextusfüggő kiindulópontból történő konstruálás miatt válhatnak a diskurzusdeixis prototipikus kifejezőeszközeivé: a diskurzusdeixis megalkotásának kiindulópontja a diskurzus azon pontja, ahol a beszélő a diskurzus megalkotásának idejében és metaforikus terében tart, ezért a diskurzus részeire történő rámutatás az időben és a térben 'közeli' részre történik, jellemzően a palatális hangrendủ névmások által (1. LACZKÓ 2019: 250-251).

A mutató névmási elemhez kapcsolódva szükséges még a konstrukciókról is szót ejteni. Amellett, hogy a palatális névmás önállóan tölti be és valósítja meg a diskurzusdeixis müveletét, ún. kifejtő használatában (LACZKÓ 2019: 251) (pl. ez a férfi, ilyen könyv) a mutató névmás és egy konceptuális főnév kapcsolódik össze. Az írott, tervezett szövegtípusokra továbbá jellemzővé válhatnak olyan nyelvi kifejezések, melyek szemantikailag kidolgozottabban teszik elérhetővé a diskurzusdeixis müveletét. Ebben az esetben a diskurzustérben történő tájékozódás 
nyelvi eszközei jelzős szerkezetek (az alábbi példa, az elözö fejezetben) vagy ezen jelzők főnevesült formái (az alábbiakban, az elöbbiekben), illetve határozószók (alább, korábban), melyek egyfelől A DISKURZUS TÉR, másfelől A DISKURZUS IDŐ metaforák által a diskurzus térbeli, illetve időbeli összetevőit helyezik a figyelem előterébe, a TÉR esetében kihasználva az írott diskurzus vizuális térfoglalásából adódó lehetőséget.

A diskurzusdeixis fontos jellemzője továbbá, hogy deiktikus funkciója mellett a koreferencia jelenségében is részt vehet, amennyiben a referenciális értelmezés megkívánja azt, hogy egy korábbi vagy egy későbbi elemet felhasználva történjen meg a feldolgozása.

A d i s kurzu s jelölők funkcionális leírása során SIEPMANN (2005) több más írott müfaj mellett írott tudományos szövegekben is vizsgálta a többszavas diskurzusjelölöket (vö. DÉR 2010). Az általa felvett funkciók közül a példaadók között (ezek a következők), illetve az előszámlálókban (egyrészt - másrészt; az alábbiakban a ...-t mutatom be) több olyan elem található, melyek ismertetése már fentebb, a diskurzusdeixisnél, a szemantikai kidolgozottsággal jellemezhető elemeknél megtörtént. Ugyanakkor az elöszámlálók között olyan elemek is elöfordulnak, melyek funkcionálisan kapcsolatot tartanak fenn a diskurzusdeixissel, de hagyományosan a diskurzusjelölök kategóriájába sorolhatók. Ennél árnyaltabbá válhat a kép, ha ezen felosztást CRIBLE (2015) felosztásának egy részével is kiegészítjük, mert abban olyan diskurzusjelölő funkciók is megjelennek, melyek további, a szöveg szerveződését érintő reflexiók megtételére alkalmas nyelvi elemeket is magukba foglalnak. CRIBLE (2015) megközelítésében a diskurzusjelölők szekvenciális funkciójához kapcsolódóan olyan aleseteket említ, melyek a szöveg szerveződésére vonatkoznak. Ezek a következők: tagolás, kezdő elem / határvonal jelzése, záró elem / határvonal jelzése, hozzáadás, felsorolás (idézi FURKÓ 2019: 21). A diskurzusjelölők funkcióinak meghatározásában a szövegszerveződésre történő reflexió kérdése SCHIFFRIN (1987) munkájában is lényeges elemmé válik: ő a textuális funkcióba sorolja ezeket az elemeket.

A szövegek szerveződését elvégző, szemantikai kidolgozottsággal jellemezhető diskurzusdeiktikus nyelvi elemek tehát a d i s k u r z u s j e l ö lő k kel tartanak fenn erős kapcsolatot, sőt bizonyos esetek - az értelmezői kerettől függően - tartozhatnak az egyik vagy a másik kategóriába, a két lehetőség közötti átmeneti kategóriát eredményezve. A diskurzusdeixis és a diskurzusjelölők ilyen domináns kapcsolata jól mutatja, hogy a metapragmatikai tudatosság szoros összefüggést mutat a nyelv metafunkcióival. Jelen esetben a szövegszerveződésre irányuló reflexiók egyaránt elösegíthetik a közös figyelmi keretben zajló interszubjektív megértést és az interperszonális kapcsolatteremtést (vö. TÁTRAI 2017: 1052). A két kategória közötti kapcsolatot a 'rámutatás' érvényesülésének mértékében lehetne összegezni, tehát abban, hogy ezen reflexiók önállóan mennyire érvényesítik, illetve mennyire képesek érvényesíteni a 'rámutatás'-t, illetve mennyire jellemzi öket a szemantikai kifejtettség. A szövegszerveződés prototipikus deiktikus nyelvi elemeiben dominánsan a 'rámutatás' valósul meg (pl. itt, ilyen); a szemantikai kifejtettséggel jellemezhető nyelvi elemekben pedig kisebb vagy nagyobb mértékben érvényesül még a szöveg részére történő 'rámutatás' lehetősége 
(pl. a következö fejezetben, végül). Utóbbiak diskurzusjelölökként is (a következö fejezetben) vagy akként (végül) értelmezhetők. A tanulmány ezért a két lehetőség összefüggését - ott, ahol ez relevánssá válik - a téma kifejtése során hangsúlyozza. A két kategóriát a vizsgálat kiindulópontja miatt viszont nem kívánja mereven szétválasztani, hiszen ezen nyelvi lehetőségek egyaránt a szöveg szerveződését teszik reflexió tárgyává.

4.1. Anyag és módszer. A vizsgálat alapja egy összesen 188 oldalnyi, 93158 szóból álló tanulmánykötet (TOLCSVAI NAGY szerk. 2006) volt. ${ }^{2}$ A vizsgálat a mintából elöször manuális úton a szöveg szerveződésére reflektáló nyelvi elemeket nyerte ki. Tehát egyaránt koncentrált azon palatális mutató névmási elemekre, melyek a diskurzusdeixis pozícióját tölthetik be, valamint - ehhez kapcsolódóan - a szemantikai kifejtettséggel jellemezhető nyelvi elemekre, továbbá azon diskurzusjelölőkre, melyek szintén a szöveg szerveződésére képesek reflektálni. ${ }^{3}$ Ezt követően manuális annotációval kvantitatív elemzést végzett. Ezen kvantitatív elemzések szolgáltak alapul az eredményekhez füződő kvalitatív megállapításokhoz.

A mutató névmási elemek bemutatásához, illetve kategóriáinak felállításához - a müfajközi összehasonlítás lehetősége miatt - a vizsgálat LACZKÓ KRISZTINA (2019) két internetes fórum elemzésével végzett kutatását vette alapul.

A kutatás továbbá az MNSZ2 (v2.0.5.) tudományos alkorpuszának 100-100 adatból álló véletlen listájával is kibővült. A vizsgálat a kutatás egy felvetésének alátámasztására, illetve a deixis múködésének árnyaltabb bemutatásához járult hozzá. Ez a kiegészítő vizsgálat a később-bel és az azonos irányt kidolgozó következö-vel konstruált nyelvi elemek közül kiválasztott 3 alakra (később, késöbbi, késöbbiekben; következö, következöben, következökben) terjedt ki, illetve a lent-tel konstruáltak közül 4 alakra (lent, lentebb, lentebbi, lenti). Az elemzés - az előfordulás mellett - arra koncentrált, hogy ezen elemek jellemzően a diskurzusdeixist, az idődeixist (a következö esetében), illetve a térdeixist (a lent esetében) vagy egyéb funkciót valósítanak meg, bemutatva a diskurzusdeixis müveletével erős kapcsolatot fenntartó deixisfajták megvalósításának és megvalósulásának lehetőségét a tudomány szakszövegeiben.

4.2. Eredmények. A vizsgálat eredményei először is arra irányították rá a figyelmet, hogy a tudomány szakszövegeiben megjelenő diskurzusdeixis funkcionálisan igen erös kapcsolatot tart fenn a tér-, illetve a helydeixissel, a diskurzusjelölőkkel és a tagmondatok közötti tartalmi-logikai kapcsolatot megjelenítő kötőszavakkal. Mindez elsősorban a mutató névmási elemeknél vált meghatározóvá. Ez összefüggésbe hozható egyfelől a diskurzusdeixis kontextusfüggő tájékozódást elvégző funkciójával, mely a diskurzus tér-, illetve időbeli aspektusát emeli ki a térdeixis $\rightarrow$ idődeixis $\rightarrow$ diskurzusdeixis (TÁTRAI 2017: 143) séma mentén. Másfelöl összekapcsolódik a mutató névmási elemek grammatikalizációs folyamatával.

${ }^{2}$ A vizsgált szövegek bibliográfiai adatait lásd a Források alatt. A mintából származó nyelvi példáknál az adott tanulmányra történik hivatkozás.

${ }^{3}$ Jelen vizsgálat nem terjed ki az idézést kísérő deiktikus nyelvi elemekre. (Ezek müködésére 1. pl. CSONTOS 2019b, 2020.) 


\section{1. ábra}

Az ez, így, ilyen és itt névmásokkal konstruált önálló és kifejtő diskurzusdeixisek eloszlása (\%)

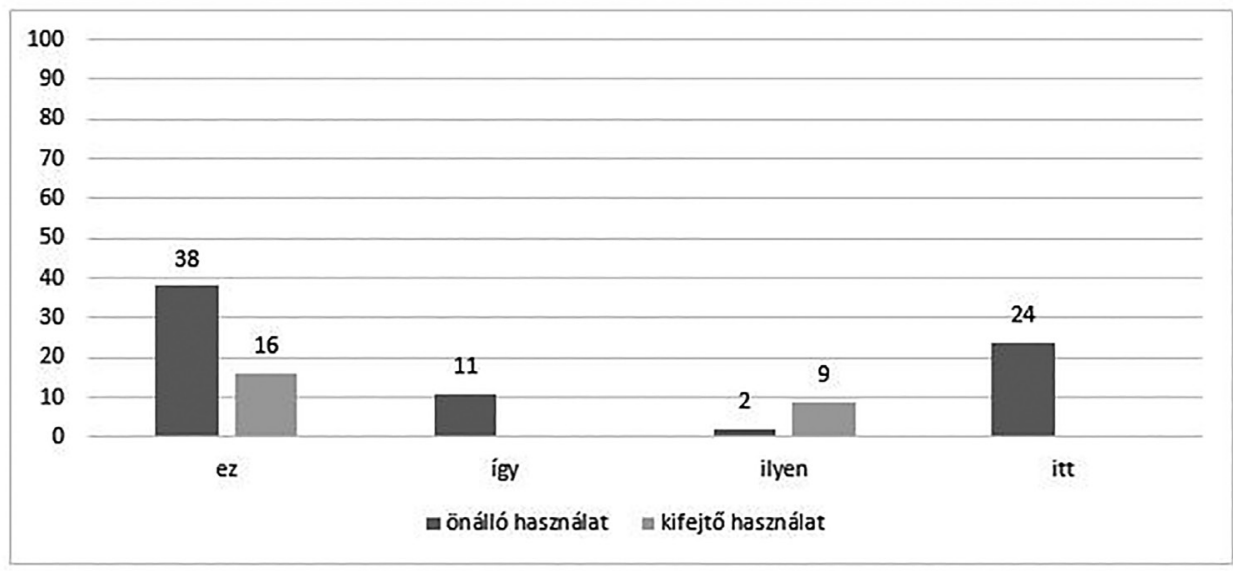

A mintában összesen 347 diskurzusdeiktikus nyelvi elem található. Az 1 . ábra alapján az mondható el, hogy ezek közül az ez-zel konstruált elemek váltak a mintában a legjellemzőbbé (54\%). Az ez alapvetően a diskurzusra mint téri entitásra képes reflektálni. Önálló használata esetén (38\%) a diskurzus szerveződését úgy teszi reflexió tárgyává, hogy a diskurzustérben való tájékozódást valósítja meg, de emellett - koreferens viszonyt is létesítve - tartalmi referenciája is érvényesül. Kifejtő használata (16\%) esetén (ez az elmélet) a tartalmi vonatkozást már a névmás után következő fónév valósítja meg, a névmás funkciója a diskurzus terében való tájékozódás megjelenítésére szükül. A két használati mód konstruálása deiktikus helyzetben eltér egymástól, az önálló használat nagyobb mentális erőfeszítést kíván meg a befogadótól. Ez válik dominánssá a vizsgált tudományos szakszövegekben. A kifejtő használattal kapcsolatban ugyanakkor az is felvethető, hogy a szövegszerveződés szempontjából kiemelkedő figura előtérbe állításának motivációja miatt él a szövegalkotó ezzel a szerkezettel. A minta alapján a kifejtő használat főnévi eleme a) a SZÖVEG SZERKEZETÉ-re, annak egy részére (ez a fejezet, kutatás, összegzés); b) az adott vagy mástól származó ELMÉLET-re vagy az elmélet egyik ÖSSZETEVÖJÉ-re (ez az elméleti keret, értelmezés, modell, megközelités); c) a MÓDSZER-re (ez a rendszerezés, módszer, kutatási irány, kutatási lehetöség, kidolgozás, vizsgálat); d) a TÁRGY-ra, a TÉMÁ-ra (ez a kutatás, téma, témafelvetés, kérdés, probléma) vonatkozik. Mindezen fogalmi tartományokkal kapcsolatban az mondható el, hogy a szöveg központi összetevőit (az elmélet, a módszer, a szerkezet) teszik elérhetővé. A mutató névmás mellett megjelenő, kettős lehorgonyzással (mutató névmás és névelő által) elérhetővé váló főnév alkalmazása ezért feltehetően abból az okból motivált, hogy a szöveg témakidolgozása során a figyelem előterébe kerüljenek azon központi összetevők, melyek a TUDÁS konstruálásának folyamatában meghatározó szerepet játszanak. 
Az ez-zel kapcsolatban még egy dolog válhat meghatározóvá: a későbbiekben bemutatásra kerülő, szemantikai kidolgozottsággal jellemezhető jelzős szerkezetek (vagy azoknak főnevesült alakjai) és határozószók origóját tehetik explicitté ezen alakok. Az ez ugyanis - az itt-hez hasonlóan - a diskurzus éppen aktuális pozícióját jelenítheti meg. Az aktuális pozíció kifejeződését a mintában leginkább az ezen a ponton kifejtő használat alkalmazása tette explicitté.

Az ilyen névmással konstruált diskurzusdeixisek (11\%) esetében szintén megfigyelhető az önálló ( $2 \%$ ) és a kifejtő ( $9 \%$ ) használat. A mutató névmási elem a diskurzus szerveződését mindkét esetben tulajdonságként profilálja. Önállóan szintén koreferens viszonyban vesz részt, kifejtő használatában (pl. ilyen módon, ilyen értelmezésben) a diskurzusdeixist - eltérően az ez-től - úgy valósítja meg, hogy a tulajdonságjelleget teszi hozzáférhetővé a diskurzustérben történő rámutatás során.

Az adverbiálisok grammatikai jellemzőjük miatt önállóan jelennek csak meg. Az így (11\%) és az itt (24\%) a diskurzus szerveződésére reflektálnak. Az így a diskurzus szerveződését módként vagy módozatként profilálja, az itt a diskurzus térbeli elrendeződését jeleníti meg.

Az így-gyel kapcsolatban előtérbe került az a grammatikalizációs ösvény, mely a diskurzusdeixistől a diskurzusszervező funkción keresztül a tartalmi-logikai viszonyt jelölő kötőszói szerepig terjed, például:

(1a) A szövegeket vizsgálhatjuk a bennük megjelenő illokúció szerint, így ${ }^{4}$ jár el például Coserieu (SZ6: 13)

(1b) Azokban a nyelvekben, amelyekben csak két (fokális) színnév van, az a lista első két tagja [...]; azokban, amelyekben három (fokális) színnév van, az a lista első három tagja, és így tovább (SZ9: 50)

(1c) Nyilvánvaló azonban, hogy szemléleti eltérés van a mai és a történeti változat között, így a nyelvészeti szövegkutatásokban felmerülő kérdésekre is különböző válaszokat kaphatunk (SZ4: 13)

Az (1a) példában az így - amellett, hogy koreferens viszony tagjává válik - a diskurzusdeixis funkcióját is betölti. Az (1b) példában a névmás deiktikus jellege háttérbe, ezzel együtt diskurzusszervező funkciója előtérbe kerül: az igy funkciója a diskurzus továbbvitelének, a további hasonló események lehetőségének jelzése (miközben még érzékelhető az anaforikus irány). Az (1c)-ben az így 'ezért' következtető jelentésben szerepel, a két tagmondat közötti tartalmi-logikai és grammatikai kapcsolatot megjelenítve. Ezen folyamat a vizsgált szövegekben kiemelkedővé válik, olykor átmenetet képezve az egyes grammatikalizációs fokok között. A mintában tehát az így nagyobb százalékban szerepelt, de ennek domináns része már az igy deszemantizációjával, illetve az arra irányuló tendenciával jellemezhető.

Az itt mutató névmási elemmel kapcsolatban a minta alapján érdemes további kiegészítéseket tenni. Megfigyelhető, hogy a mintában ez a nyelvi lehe-

${ }^{4}$ A tanulmány teljes terjedelmében a példákban alkalmazott kiemelések tőlem származnak (Cs. N.) 
tőség valósítja meg a mutató névmások közül legtisztábban a diskurzusdeixis mủveletét. A névmás ugyanis a diskurzus adott terére képes rámutatni, a diskurzus térbeli elrendeződését önmagában képes reprezentálni. A diskurzustérre történő rámutatás alapján az itt-nek három alapvető funkcióját lehet a vizsgált szövegekben megkülönböztetni.

(2a) a 'minta' fogalma itt úgy értelemezhető (SZ4: 27)

(2b) a szövegtipológiai kutatások történetét itt nem szükséges részletesen összefoglalni (SZ9: 45)

(2c) itt pusztán néhány példát mutattam arra nézve (SZ2: 76)

(2d) itt ahelyett az az érdekes (SZ5: 127)

(2e) ebből elsők között veszi ki részét Bitnitz itt tárgyalt munkája is (SZ4: 30)

(2f) E szempontok alapján könyve három részre oszlik: az első az irálytan (stilisztika) általános kérdéseit tárgyalja, itt esik szó a müfaji alapformák mellett (SZ4: 33)

Az itt - mint az a (2a-b) példában látható - egyfelől metonimikusan utalhat a teljes szövegre, kijelölve az adott diskurzust hasonló témában íródott, hasonló megközelítést alkalmazó szövegek közül. Másfelöl - mint az a (2c-d)-ben megfigyelhetö - a szöveg éppen aktuális pozíciójára képes rámutatni. A harmadik eset (2e-f) azon lehetöségek jelölését öleli fel, mikor az aktuális megnyilatkozó a diskurzusában az intertextualitás lehetőségét kihasználva más szövegekre hivatkozik, majd ezen szövegekre, illetve az azokban elötérbe kerülö összetevőkre - a (2a-b)-hez hasonlóan - az itt-tel mutat rá. Az itt ebben az esetben az aktuális diskurzus részévé válik, ezért az aktuális megnyilatkozó pozíciójához, illetve az aktuális diskurzushoz való 'közelség'-et kifejezve tudja elvégezni a rámutatást.

Az itt alkalmazásával kapcsolatban a vizsgálat azt is elemezte, miért él az aktuális megnyilatkozó az adott pozícióra történő rámutatás nyelvi lehetőségével. A vizsgált mintában az itt deiktikus elem használatát leginkább a diskurzus szerveződésének folyamatához lehet kapcsolni, az itt-et ugyanis minden esetben az adott téma kifejtésének szempontjából releváns információk átadása követi. Ezek egyfelől az elmondottakhoz füzött beszélői reflexiók, vélemények, másfelől a TUDÁS megosztásának folyamatából kiemelkedő, központi összetevők, illetve összegzések. A szövegekben a megnyilatkozó ezen összetevőkre az itt alkalmazásával tudja a figyelmet irányítani, a gondolatmenetében, a szöveg folyamatában az itt által kijelöli azt a pozíciót, melyet a TUDÁs megosztása szempontjából fontosnak vél. Mindezt az itt-et kísérő nyelvi eszközök is kifejtetté tehetik, például:

(3a) Itt említem meg azt az emlékezet kapcsán is felmerülő problémát (SZ1: 96) 
(3b) Mi itt [...] a számunkra leginkább elfogadható felfogást foglaljuk össze (SZ3: 177)

A (3a-b) példák mellett az itt, illetve az itt-tel jelölt diskurzusrész az origóját képezheti azon - a későbbiekben bemutatásra kerülő - szemantikai kifejtettséggel jellemezhető deiktikus nyelvi elemeknek, melyek a diskurzus korábbi vagy későbbi részeire képesek utalni.

Aszemantikai kifejtettséggel jellemezhető diskurzusd e i x i s ek a tudomány szakszövegeinek jellemzőivé válnak (DÉR 2010: 382-388; KERTES é. n. 70-71). Ezen nyelvi lehetőségek funkciójukat tekintve a prototipikus diskurzusdeixis és a diskurzusjelölők közötti átmeneti kategóriát valósítják meg. Megelőlegezve a minta alapján látható, a későbbiekben kifejtésre kerülő és példákkal alátámasztott megállapításokat, ez a szemantikai összetettségben összegezhető: ezen elemek épp a szemantikai komplexitásukkal gyengítik a 'rámutatás' funkcióját, de ezzel párhuzamosan képesek nagyobb hatótávolságra utalni, illetve egy, már említett elemet nagyobb hatótávolságban, az új kotextusban újrafogalmazni, újraértelmezni. Mindebből látható, hogy a 'rámutatás' összetevő egyfelől - a fönév vagy a főnevesült tag szemantikája miatt - kiegészül, másfelől - a kiegészülés következményeként - a 'rámutatás' mozzanata a prototipikus deiktikus nyelvi elemekhez képest a szerkezeti szinten is megmutatkozó szemantikai komplexitás miatt finoman csökkeni kezd.

A szemantikai kifejtettséggel jellemezhető nyelvi lehetőség a mintában öszszesen 193 esetben fordult elő. A mutató névmási elemek előfordulási adatával összehasonlítva (347) előtérbe kerülhet annak a kérdése, hogy mi az alapvető különbség a két eljárásmód között. Mivel a szemantikai kifejtettség a határozószók, illetve a főnevesült jelzők esetében hasonlónak tekinthető, ezért ezt a magyarázó okot a vizsgálat elveti. Sokkal inkább a diskurzus szerveződésével való összefüggéssel látja ezt magyarázhatónak, közelebbröl a diskurzusdeiktikus nyelvi elemek - az imént említett - hatótávolságával, illetve a 'közelség', 'távolság' kifejeződésével. A mutató névmási elemek ugyanis (önálló és kifejtő használatban is) elsősorban az elemi események reprezentációjaként értelmezett tagmondatok között érvényesülnek, illetve a 'rámutatás' müveletét kisebb hatótávolságú szövegegységek esetében képesek elvégezni. A prototipikus diskurzusdeixist elvégző palatális mutató névmások - funkciójukból adódóan - az adott pozícióra, illetve a megnyilatkozóhoz közel levő entitásokra, helyzetekre, diskurzusösszetevőkre és módokra, körülményekre képesek rámutatni. A szemantikai kifejtettséggel jellemezhető nyelvi elemek viszont nagyobb hatókörrel rendelkeznek: az elöre-, illetve hátrautalás során jellemzően nagyobb távolságot tudnak megjeleníteni, mint a mutató névmási eszközök; funkciójuk is leginkább abban összegezhetö, hogy az adott pozíciótól távolabb elhelyezkedő diskurzusrészekre képesek utalni.

A diskurzusdeixis megvalósításának tipikus nyelvi lehetőségei egyfelől aszerint kategorizálhatók, hogy az aktuális diskurzuspozíció elött vagy után megjelenő diskurzusrészre utalnak. 


\section{2. ábra}

Szemantikai kifejtettséggel jellemezhető diskurzusdeiktikus elemek eloszlása az irány alapján (\%)

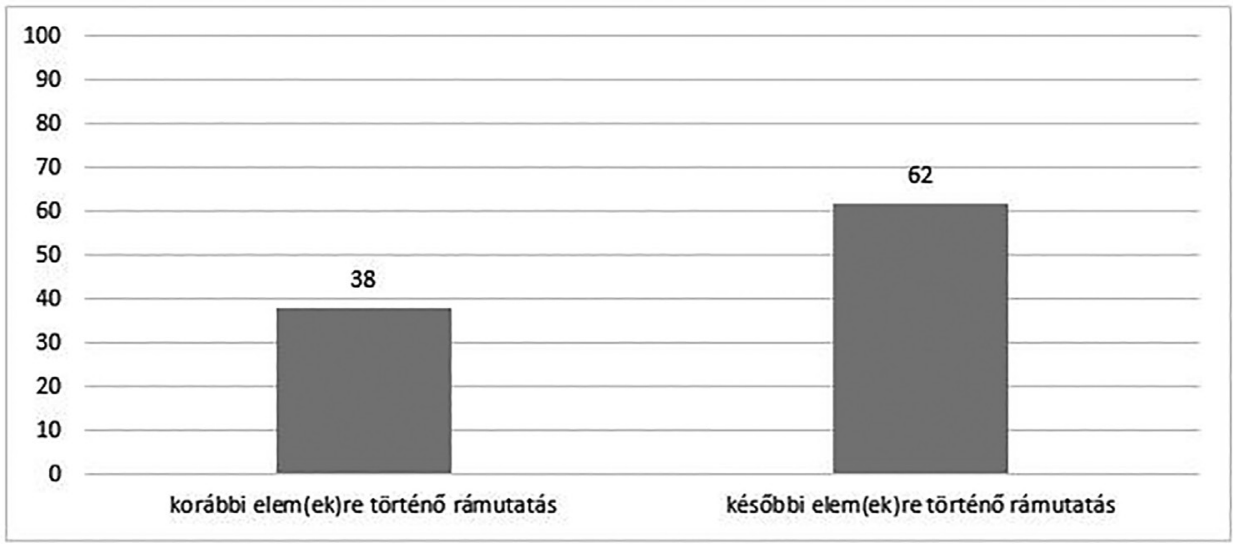

A mintában az adott pozícióhoz képest korábbi szövegösszetevőre (38\%), illetve a későbbiekre (62\%) történő rámutatás (1. 2. ábra) a szövegek megértési és értelmezési útvonalát mutathatja, illetve az válhat a diskurzus szerveződésére történő reflexiók alkalmazásának alapjává. A szövegalkotó figyelembe veheti azon befogadói elvárást, hogy a fogalmilag már kifejtett tudásösszetevőket csak akkor hozza ismét mozgásba, amikor azoknak megismétlése, hivatkozással történő felidézése, illetve újrafogalmazása az adott diskurzushelyen relevánssá válik. Ezekben az esetekben a diskurzusdeixis által az adott szövegrész, tudásöszszetevő ismét az aktív figyelem zónájába kerülhet úgy, hogy a diskurzus éppen aktuális helyén újrafogalmazódik, újraértelmeződik, viszonyba kerülve az azon a ponton kifejtésre kerülö tudásösszetevőkkel, fogalmi összetevőkkel. A későbbi részekre történő utalás az „új információ” fogalmát valósítja meg. Az előreutalás a befogadó számára kijelöl egy értelmezési ösvényt is, melynek során vagy végpontján egy tudásösszetevő - a szemantikai kifejtettséggel jellemezhető deiktikus nyelvi elemnek köszönhetően - már valamilyen fokon elökészítettnek tekinthető. A későbbi elemre történő, szemantikai kifejtettséggel történő utalás tehát azért válhat gyakoribbá, mert a szövegalkotó egy olyan elemet kíván müködésbe, illetve viszonyba hozni az éppen aktuális pozíció egyik elemével, melynek fogalmi kifejtése még nem történt meg.

Mind az előre, mind a hátrautalást eltérö kifejtettségü elemek végezhetik el. A mintában egyaránt megtalálhatók a nagyobb kifejtettséggel jellemezhető jelzős szerkezetek (pl. a fentebb mondottak, a fentebb szóba került, az alábbi fejezetben stb.) és az ezen szerkezetek jelzőinek fönevesült alakjai (a fentebbiek), illetve különböző határozószók (pl. lent, lentebb). Az első konstrukcióval kapcsolatban az mondható el, hogy a deixis múveletét a jelzői szerepben álló deiktikus nyelvi elem végzi el, akárcsak a főnevesült alakok szótöve, illetve a határozószói alak. Amíg viszont a komplex szerkezet (az alábbi fejezet) egyszerre hoz mozgásba HELY-et 
(fejezet), illetve POZícIÓ-t (alábbi), addig a másik két alak csupán az éppen aktuálishoz viszonyított POZícIÓ-t profilálja, a helyzetkijelölés nem specifikálódik. Ezért a vizsgálat ezen összetettséget, jelentéskidolgozást előtérbe helyezve elemzi a továbbiakban ezen deiktikus elemeket (tehát a HELY-re való utaltság vagy annak elmaradása alapján beszél kifejtett és nem kifejtett nyelvi elemekről).

\section{3. ábra}

A fent, elöbb, utóbb, alább, korább(i), később(i), elözö és következö elemekkel konstruált kifejtett és nem kifejtett diskurzusdeixisek aránya (\%)

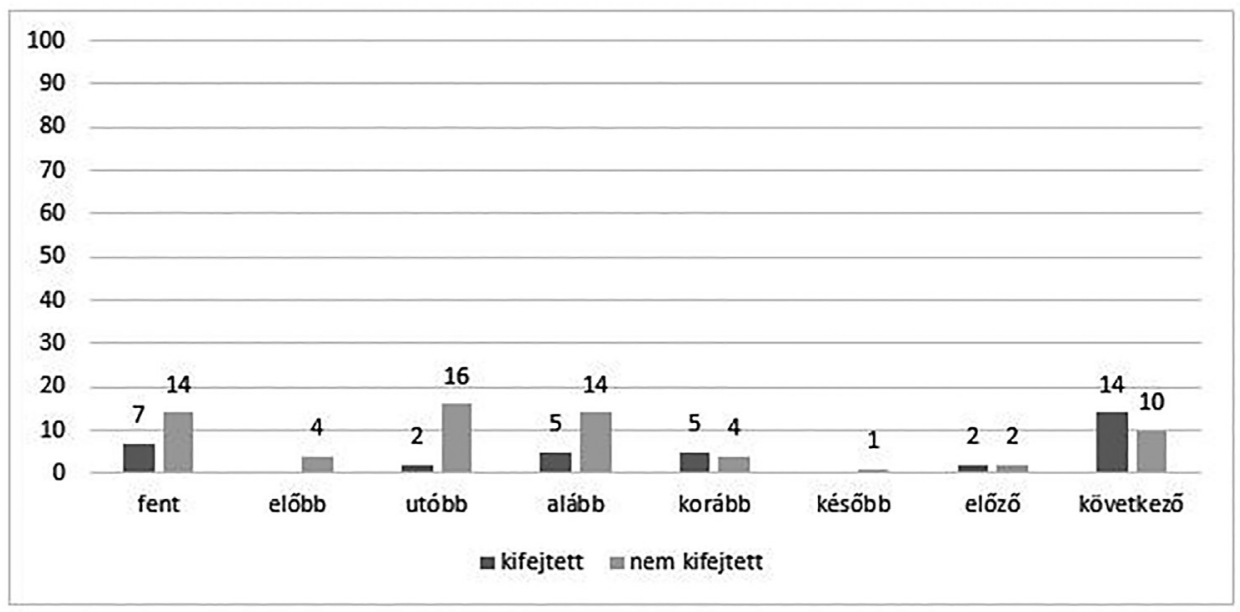

Mint az a 3. ábrán látható, alapvetően a nem kifejtett elemek alkalmazása jellemzi a tudomány szakszövegeiből álló mintát. A kifejtett elemek (szerkezetek) főnévi tagja egyaránt megjeleníthet a szöveg szerveződésének szempontjából releváns elemet (pl. [az elözö, fentebbi] pont, rész, fejezet stb.), illetve a tudás öszszetevőit (pl. lehetöség, elméleti keret, kérdés, mondottak, példa). Mint arról már volt szó, ezen nyelvi elemek nagyobb távolságot tudnak megjeleníteni, mint a mutató névmásiak. A távolság profilálása szempontjából viszont több fokozat valósul meg. Az előbb-bel és az utóbb-bal konstruált elemek alkalmazása jellemzően egy tagmondatnyi (mondatnyi) távolságban valósul meg. Ezzel magyarázható, hogy egyiket sem jellemzi a kifejtettség, hiszen a szöveg adott összetevői még az aktív figyelmi zónában lehetnek. Ebből kiindulva a többi elemre nézve a 'távolság' mértékének szempontjából az mondható el, hogy minél távolabbi összetevőt tesz reflexió tárgyává a beszélő, annál magasabb fokú kifejtettséget alkalmaz. A relatív nagyobb 'távolság'-ot megvalósító fent-tel konstruált elemek (,párja”, a lent a mintában egyszer sem fordult elő) nem kifejtő alkalmazása továbbá az 'összegző' jelentést tudja megvalósítani, tehát mindazon elemekre képes utalni, melyek az aktuális pozícióig kidolgozásra kerültek (pl. a fentebbiek alapján 'az eddig elmondottak alapján'). A később(i) emelkedik még ki a felsorolt elemek közül. Ezzel kapcsolatban a vizsgálat azzal a felvetéssel él, hogy ez az elem, illetve az ezzel 
az elemmel konstruált szerkezetek jellemzően a TUDÁs megosztásában, a TUDÁS összetevőinek egymáshoz való viszonyában vállalnak szerepet (pl. a későbbi elméletek, a későbbiekben 'időben később'), a szöveg időjelölését, az idődeixist megvalósítva. A diskurzus szerveződésére történő reflexiók megtételére talán ezért nem alkalmazzák.

A minta alapján kirajzolódó ezen felvetést a vizsgálat az MNSZ2 (v2.0.5.) tudományos alkorpuszának 100-100 adatból álló véletlen listáján is elemezte. ${ }^{5}$ A vizsgálat a késöbb-bel és az azonos irányt kidolgozó következö-vel konstruált nyelvi elemek közül kiválasztott 3 alakra (később, késöbbi, késöbbiekben; következö, következöben, következökben) terjedt ki, illetve a lent-tel konstruáltak közül 4 alakra (lent, lentebb, lentebbi, lenti), ${ }^{6}$ mivel ez az elem nem jelent meg a vizsgált mintában. Az elemzés - az előfordulás mellett - arra koncentrált, hogy ezen elemek jellemzően a diskurzusdeixist, az idődeixist (a következö esetében), illetve a térdeixist (a lent esetében) vagy egyéb funkciót valósítanak meg. Az eredmények a következők.

\section{4. ábra}

A lent, a következő és a később nyelvi elemekkel konstruált kifejezések előfordulása az MNSZ2 (v2.0.5.) tudományos alkorpuszában (\%)

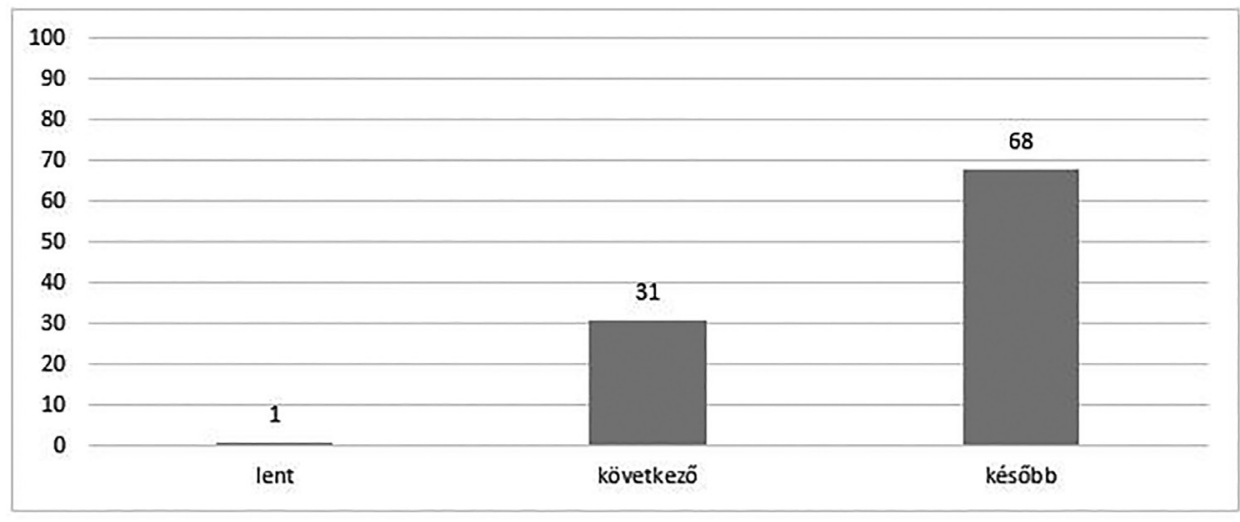

Mint a 4. ábrán látható, a tudományos alkorpuszban a vizsgált lent-tel konstruált elemek száma a legalacsonyabb (1\%, összesen 1621 előfordulás; a vizsgált elemekre lebontva: lent: 870 , lentebb: 292, lenti: 437, lentebbi: 22), a következö elemmel konstruáltak (31\%) összesen 54005 esetben (a vizsgált elemekre lebontva: következö: 53 265, következöben: 51, következökben: 689), a késöbb-bel (69\%) pedig 116400 előfordulás (később: 88 574, későbbi: 24 110, későbbiekben: 3716). Izgalmasabbá válik a kép, ha a három elemmel konstruált 100-as véletlen listákat vizsgáljuk.

${ }^{5}$ Lehívás dátuma: 2020. 06. 01.

${ }^{6}$ A később-bel és a következö-vel konstruált nyelvi alakok kiválasztása az elöző vizsgálat alapján történt: a 3 leggyakoribb elem került elemzésre; a lent esetében - mivel az előző vizsgálati anyagban nem jelent meg - intuíció alapján kerültek kiválasztásra az alakok. 


\section{5. ábra}

A lent-tel, a következö-vel és a később-bel konstruált nyelvi elemek funkciói az MNSZ2 (v2.0.5) véletlen mintáiban (\%)

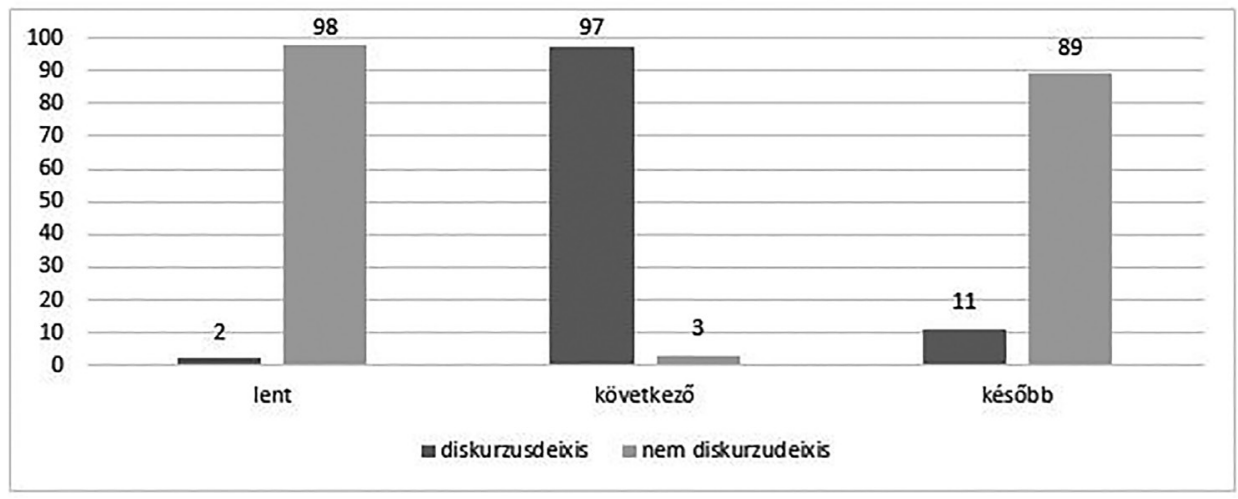

A lent csupán 2\%-ban valósítja meg a diskurzusdeixis múveletét, de a konstruálási mód is jellemzővé válik rá: a véletlenszerủ mintában (5. ábra) leginkább hivatkozásokban szerepel (pl. l. lent, lentebb). Ezekben az esetekben A DISKURZUS TÉR metafora lép müködésbe. A következö esetében ez az arány megfordul: ezen nyelvi elemmel konstruált kifejezések 97\%-ban a diskurzusdeixis müveletét valósítják meg, 3\%-ban pedig idődeixisként funkcionálnak (pl. a következö munkájában, a következö években). Így itt a diskurzusdeixis alapja A DISKURZUS IDŐ lehet. A 'távolság'/'közelség' megállapításához a vizsgálat arra is kiterjedt, hogy megnézze, milyen 'távolság'-ban levő elemekre mutatnak rá a következövel konstruált elemek: jellemzően egy tagmondatnyi a „rámutatás” távolsága (pl. a következö:, a következö példák stb.), kivételt képez a következökben, mely - a többes szám miatt - több tagmondatnyi távolságra (is) képes rámutatni. A később esetében pedig 11\%-ban lehet diskurzusdeixisről beszélni, a többi esetben az ezzel konstruált nyelvi elemek idődeixist valósítanak meg (pl. későbbi századok, a későbbi munkák, a későbbiekben született elméletek). Kiemelkedővé válik az is, hogy a diskurzusdeixis megvalósítása itt is elsősorban a hivatkozások által megy végbe (az esetek 97\%-ában valósult ez meg, pl. l. később). Ebben az esetben tehát ismét A DISKURZUS IDŐ válhat a diskurzusdeixis alapjává. A lent, illetve a később elemmel konstruált nyelvi kifejezések alkalmazása nagyobb 'távolság'-ot valósít meg, mint a következö esetében.

Az 5. ábrán szereplő elemek elsősorban A DISKURZUS TÉR metaforát használják fel. Ennek alapja az írott nyelvi diskurzus térbeli kiterjedése lehet, tehát a diskurzus mint tárgyiasított entitás jelenik meg. A diskurzusdeixis e lehetősége így a vizualitást helyezi előtérbe e deiktikus nyelvi elemek szerveződésekor és nem az IDŐ-t előtérbe állító befogadási folyamatot.

Itt szükséges arról szólni, hogy ezen nyelvi lehetőségek szintén erős kapcsolatot tartanak fenn a diskurzusjelölökkel. Nem csupán azért, mert az adott szövegtípusra jellemzővé válik az alkalmazásuk, hanem azért, mert itt is megfigyelhető 
az a deszemantizáción alapuló vagy afelé haladó grammatikalizációs folyamat, mely a mutató névmásoknál észlelhető. Továbbá bizonyos, a szöveg szervezödésére utaló diskurzusjelölők e deiktikus nyelvi elemekkel mutatnak igen nagy hasonlóságot, például elöször - másodszor, egyrészt - másrészt stb.

A rámutatásnak és a diskurzus szerveződésének sajátos példájává válhat még további, a szövegeket nagyban jellemző két eset, ezek a l. ('lásd') és a vö. ('vesd össze'), melyek egy külső entitásra történő rámutatás megvalósítása során a szövegvilág részévé az intertextualitás lehetőségét kihasználva tehetnek az adott szövegtől „távolabb levő" szövegeket.

A mintában - mint az egyfelől az elözőekben is látható - a szöveg szervezödéséhez kapcsolódó elemek olyan d is kurzu s j e lölök et is tartalmaztak, melyek egyfelől a diskurzusdeixis jelenségével tartanak fenn erős kapcsolatot, másfelöl azon kívül helyezkedhetnek el. Az elemzett mintában a diskurzusdeixissel kapcsolatot fenntartó, a szöveg szerveződését reflexió tárgyává tevő diskurzusjelölők a következők:

\section{6. ábra}

A szekvenciális funkciót megvalósító szövegszervező diskurzusjelölők a mintában $(\%)$

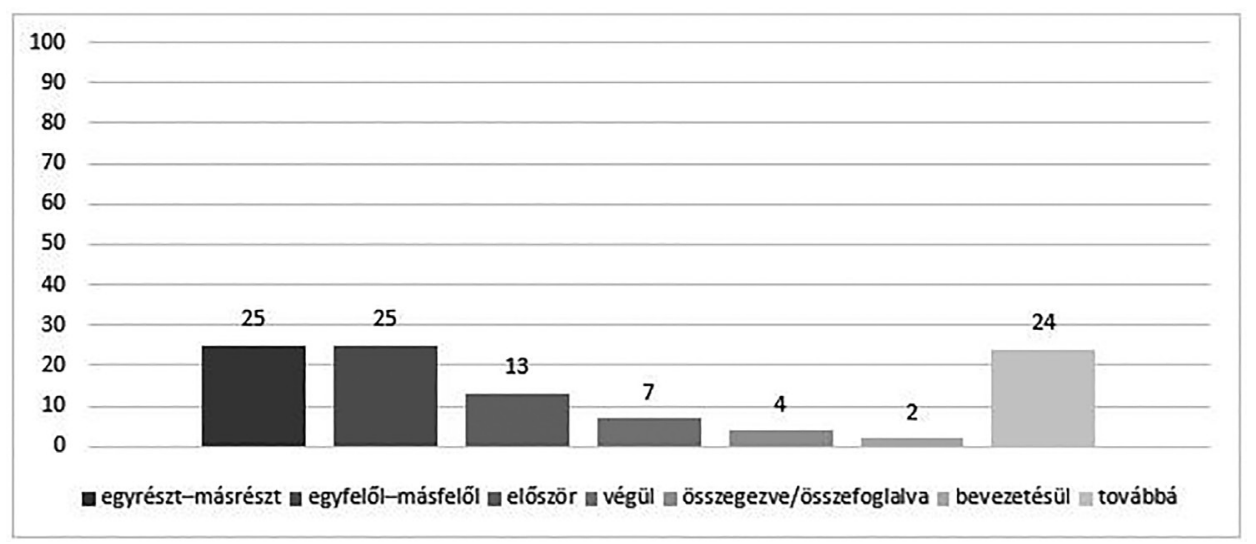

A 6. ábra diskurzusjelölőinek elsődleges funkciója a szöveg szerveződésére való reflexiók megtétele. CRIBLE (2015) felosztását követve ezek a nyelvi elemek elsősorban a tagolás, a kezdő és a záró elem jelölése, a felsorolás funkcióit valósítják meg. A tipikussá váló elemek funkciójukon kívül hatókörükben térnek el egymástól. Kisebb hatókörrel jellemezhető például az egyrészt - másrészt, ennél nagyobbal a végül vagy a bevezetésül, illetve a már a deixis témakörében tárgyalt, átmeneti kategóriába sorolható alábbi fejezetben, későbbi részekben. A továbbá némiképp kiemelkedik ebből a sorból, hiszen ez már egyéb textuális funkcióval is jellemezhető.

A diskurzusjelölők ezen csoportjához kapcsolódóan érdemes a fejezetcímekről, illetve azok közül is a kezdő- (bevezetés), illetve a záróformulákról (összegzés, összefoglalás, konklúzió) szólni. Ezek a tudományos szakszövegekben jellemzően 
konvencionalizált címek - az egyéb (fejezet)címekhez hasonlóan - ismét a deixis és a diskurzusjelölők közötti kapcsolatot tehetik explicitté: egyszerre mutatnak rá egy adott szövegrészre, és egyszerre teszik reflexió tárgyává a szöveg szerveződését.

5. Konklúziók. A tanulmány a diskurzus szerveződését reflexió tárgyává tevő lehetőségeket a tudomány szakszövegeiben vizsgálta. Ekképp előtérbe a diskurzusdeixist prototipikusan megvalósító nyelvi elemek, a diskurzusjelölők, illetve e két nyelvi lehetőség közötti átmeneti kategóriák kerültek. E nyelvi lehetőségeket a tudomány szakszövegeire mint metadiskurzusokra jellemzővé váló metapragmatikai reflexivitás tartja össze. Ezen vizsgálati szempontból a szöveg szerveződésére reflektáló nyelvi elemek inkább összetartóknak, semmint széttartóknak tekinthetők: általuk a szövegalkotó a szöveg bizonyos részeire képes reflektálni, a tudáskonstruálás szempontjából előtérbe helyezve, újra mozgásba hozva, aktivizálva vagy éppen újrafogalmazva egy már említett vagy a szövegben a későbbiekben kifejtésre kerülő nyelvi elemet. Ezen két nyelvi lehetőség összetartozásának vagy hasonlóságának tehát a szövegszerveződés, illetve a tudomány szakszövegeiben zajló tudáskonstruálás felöl nézve az az alapja, hogy a szövegalkotó a TUDÁs hozzáférhetővé tételének, illetve annak megosztásának, végső soron a szöveg megértésének és értelmezésének útvonalát jelöli ki, annak egy-egy összetevőjét előtérbe állítva. Ebből következve a szövegalkotónak a diskurzus szerveződésére történő metapragmatikai reflexiói a szubjektivizáció eszközeinek tekinthetők, mert a szövegalkotó úgy teszi reflexió tárgyává a szöveg elrendeződését, hogy saját perspektíváját közvetlen módon nem jelöli. A metapragmatikai tudatosság ezen jellemző kifejezőeszközei eltérő módon járulhatnak hozzá a TUDÁs megosztásának folyamatához, annak elérhetővé tételéhez. E nyelvi lehetőségek közös összetevőjének a 'rámutatás' tartható, de ezt eltérő mértékben és eltérő hatótávolságban valósíthatják meg. Mindezzel együtt a 'rámutatás' mellett képessé válhatnak más funkciót is megvalósítani.

Kulcsszók: tudomány szakszövegei, metadiskurzus, szövegszerveződésre irányuló metapragmatikai reflexiók, diskurzusdeixis, diskurzusjelölők.

\section{Források}

MNSz2. = Magyar Nemzeti Szövegtár 2. (v2.0.5.) http://clara.nytud.hu/mnsz2-dev

SZ1 = ANDÓ ÉVA 2006. A beszélt nyelvi történetmondások elemzésének kognitív és funkcionális szempontjai. In: TolCSVAI NAGY szerk. 2006: 81-114.

SZ2 = DOBI EDIT 2006. A formális nyelvi elemzés lehetőségei a szövegek reprezentációjában. In: TolCSVAI NAGY szerk. 2006: 64-79.

SZ3 = EŐRY VILMA 2006. A szöveg időszerkezete mint szövegtipológiai jellemző. In: TOLCSVAI NAGY szerk. 2006: 173-194.

SZ4 = FEHÉR ERZSÉBET 2006. Szövegtipológia a retorikai hagyományban. In: TOLCSVAI NAGY szerk. 2006: 18-43.

SZ5 = HÁMORI ÁGNES 2006. A társalgási müfajokról. In: TOLCSVAI NAGY szerk. 2006: $115-133$. 
SZ6 = KOCSÁNY PIROSKA 2006. A szövegtipológia eredményei és/vagy eredménytelenségei. In: TOLCSVAI NAGY szerk. 2006: 11-17.

SZ7 = TAKÁCS SZILVIA 2006. Folklorisztikai szövegtipológia - az epikus ráolvasó imádságok. In: TOLCSVAI NAGY szerk. 2006: 134-155.

SZ8 = TÁTRAI SZILÁRD 2006. A narratív diskurzusokról - pragmatikai nézőpontból. In: TOLCSVAI NAGY szerk. 2006: 157-172.

SZ9 = TOLCSVAI NAGY GÁBOR 2006. A szövegtipológia megalapozása kognitív nyelvészeti keretben. In: TOLCSVAI NAGY szerk. 2006: 64-90.

Tolcsvai NAgy GÁBor szerk. 2006. Szöveg és típus. Szövegtipológiai tanulmányok. Tinta Könyvkiadó, Budapest.

\section{Hivatkozott irodalom}

CRIBLE, Ludivine 2015. Discourse markers and (dis)fluency. John Benjamins, Amsterdam-Philadelphia.

CSONTOS NÓRA 2019a. A müszaki szöveg szövegtipológiai elemzése. A használati utasítás szövegtipológiai elemzése. In: FóRIS ÁGOTA - BÖLCSKEI ANDREA szerk., Dokumentáció, tartalomfejlesztés és szakírás. KRE-L'Harmattan, Budapest. 147-168.

CSONTOS NóRA 2019b. Kontextualizáció, konstruálás, idézés. Az idézés adaptív tevékenysége a mond-dal alkotott idézésekben. In: LACZKÓ KRISZTINA -TÁTRAI SzILÁRD szerk., Kontextualizáció és metapragmatikai tudatosság. ELTE Eötvös József Collegium, Budapest. 113-135.

CSONTOS NóRA 2020. Az idézés müködése az egyetemi tankönyvekben. In: LUDÁNYI ZSÓFIA - JÁNK ISTVÁN - DOMONKOSI ÁGNES szerk., A nyelv perspektívája az oktatásban. Líceum Kiadó, Eger. 209-224. https://doi.org/10.17048/Pelikon2018.2020.209

DÉR CSILla IlONA 2009. Mik is a diskurzusjelölök? In: KESZler BORBÁlA - TÁTRAI SZILÁRD szerk., Diskurzus a grammatikában - grammatika a diskurzusban. Tinta Könyvkiadó, Budapest. 293-303.

DÉR CSILLA ILONA 2010. Diskurzusjelölők a tudományos nyelvhasználatban. In: ZIMÁNYI ÁRPÁD szerk., A tudomány nyelve - a nyelv tudománya. MANYE - Eszterházy Károly Főiskola, Székesfehérvár-Eger. 382-388.

DÉR CSILLA ILONA 2019. Tudományos műfajok - szaknyelvi műfajok. In: FóRIS ÁGOTA BÖLCSKEI ANDREA szerk., Dokumentáció, tartalomfejlesztés és szakírás. KREL'Harmattan, Budapest. 131-146.

FURKÓ B. PÉTER 2019. Diskurzusjelölők és egyéb diskurzuspragmatikai eszközök forgatókönyvek, tankönyvek és irodalmi szövegek párbeszédeiben. Debreceni Egyetemi Kiadó, Debrecen.

GRUBER, HELMUT - RHEINDORF, MARKUS - WETSCHANOW, KARIN - REISIGL, MARTIN Muntigl, Peter - Czinglar, Christine 2006. Genre, Habitus und wisseschaftliches Schreiben. LIT, Münster.

KeRTES PATRÍCIA é. n. A metapragmatikai tudatosság jelzései érvelö érettségi szövegekben. http://www.nytud.hu/alknyelvdok11/proceedings11/kertes.pdf (2020. 06. 01.)

KULCSÁR SZABÓ ERNŐ 2017. Megértés - történés - létesülés. In: TOLCSVAI NAGY GÁBOR szerk., Megértés és megértetés. Magyarázat a bölcsészettudományokban. Gondolat Kiadó, Budapest. 13-37. 
KunA ÁGNES 2016. Az orvosi recept mint szövegtípus a 16-17. században. 1. rész. Magyar Nyelv 112: 385-400. https://doi.org/10.18349/magyarnyelv.2016.4.385

KunA ÁGNES - HÁMORI ÁGNES 2019. „Hallgatom, mi a panasz?”. A metapragmatikai reflexiók szerepei és mintázatai az orvos-beteg interakcióban. In: LACZKÓ KRISZTINA - TÁTRAI SzILÁRD szerk., Kontextualizáció és metapragmatikai tudatosság. ELTE Eötvös József Collegium, Budapest. 215-240.

KUNA ÁGNES - LUDÁNYI ZSÓFIA 2019. Terminológiai elvek az orvosi szaknyelvben és a gyógyító kommunikációban. Problémák, tendenciák, ideológiák. In: FóRIS ÁGOTA BÖLCSKEI ANDREA szerk., Terminológiastratégiai kihívások a magyar nyelvterületen. L'Harmattan - Offi Zrt., Budapest. 120-139.

LACZKÓ KRISZTINA 2008. A mutató névmási deixisről. In: TOLCSVAI NAGY GÁBOR LADÁNYI MÁRIA szerk., Általános Nyelvészeti Tanulmányok XXII. Tanulmányok a funkcionális nyelvészet köréből. Akadémiai Kiadó, Budapest. 309-347.

LACZKÓ KRISZTINA 2010. Demonstrative pronouns in space deixis, discourse deixis, and anaphora. Acta Linguistica Hungarica 57: 99-117. https://doi.org/10.1556/aling.57. 2010.1.5

LACZKÓ KRISZTINA 2019. A diskurzusdeixis mint a metapragmatikai tudatosság kifejezője. In: LACZKÓ KRISZTINA - TÁTRAI SZILÁRD szerk., Kontextualizáció és metapragmatikai tudatosság. ELTE Eötvös József Collegium, Budapest. 241-264.

LACZKÓ KRISZTINA - TÁTRAi SZILÁRD 2012. Személyek és/vagy dolgok. A harmadik személyü és a mutató névmási deixis a magyarban. In: TOLCSVAI NAGY GÁBOR TÁTRAI SzILÁRD szerk., Konstrukció és jelentés, Tanulmányok a magyar nyelv funkcionális kognitív leírására. Eötvös Loránd Tudományegyetem, Budapest. 231-257.

LANGACKER, RONALD W. 1987. Foundations of Cognitive Grammar. Volume 1. Theoretical prerequisites. Stanford University Press, Stanford.

LANGACKER, Ronald W. 2008. Cognitive grammar. A basic introduction. Oxford University Press, Oxford.

Levinson, Stephen C. 1983. Pragmatics. Cambridge University Press, Cambridge.

LeVinson, StePhiXis C. 2004. Deixis. In: Horn, LAURENCE R. - WARD, GREGORY eds., The handbook of pragmatics. Blackwell, Oxford. 97-121.

Marmaridou, Sophia S. 2000. Pragmatic meaning and cognition. John Benjamins, Amsterdam-Philadelphia.

PARODI, GIOVANNi 2009. Written genres in University Studies. Evidence from an Academic Corpus of Spanish in Four Disciplines. In: BAZERMAN, CHARLES et al. eds., Genre in a changing world. WAC Clearinghouse, Colorado. 483-502. https://doi. org/10.37514/PER-B.2009.2324.2.24

RoElCKe, THORSTEN 2002. Fachsprache und Fachkommunikation. Der Deutschunterricht 54/5: 9-20.

SANDERS, JosÉ - SPOOREN, WilberT 1997. Perspective, subjectivity, and modality from a cognitive point of view. In: LIEBERT, WOLF-ANDREAS - REDEKER, GISELA WAUGH, LINDA eds., Discourse and perspective in cognitive linguistics. John Benjamins, Amsterdam-Philadelphia. 85-112. https://doi.org/10.1075/cilt.151.08san

SCHIFFrin, DeBORAH 1987. Discourse Markers. Cambridge University Press, Cambridge. 
SIEPMANN, DIRK 2005. Discourse markers across languages. A contrastive study of second-level discourse markers in native and non-native text with implications for general and pedagogic lexicography. Routledge, Abingdon - New York.

TAAVITSAINEN, IRMA - JUCKER, ANDREAS H. 2010. Trends and developments in historical pragmatics. In: JUCKER, ANDREAS H. - TAAVITSAINEN, IRMA eds., Historical pragmatics. Handbooks of pragmatics 8. De Gruyter Mouton, Berlin - New York. 3-30. https://doi.org/10.1515/9783110214284.1.3

TÁTRAI SZILÁRD 2011. Bevezetés a pragmatikába. Funkcionális kognitív megközelités. Tinta Könyvkiadó, Budapest.

TÁTrAi SZILÁRD 2017. Pragmatika. In: TolCSVAI NAGY szerk. 2017: 897-1058.

TOLCSVAI NAGY GÁBOR 2017a. A nyelv emberi lényege, A magyarázat látóköralkotó változatai a nyelvtudományban. In: TOLCSVAI NAGY GÁBOR szerk., Megértés és megértetés. A magyarázat a bölcsészettudományokban. Gondolat Kiadó, Budapest. 38-62.

Tolcsvai NAgY GÁBOR 2017b. Bevezetés. In: TolCSVAI NAGY szerk. 2017: 23-71.

TolCSVAi NAGY GÁBOR 2017c. Jelentéstan. In: TolCSVAI NAGY szerk. 2017: 207-466.

TOlCSVAI NAGY GÁBOR szerk. 2017. Nyelvtan. Osiris Kiadó, Budapest.

Verschueren, JeF 1999. Understanding pragmatics. Arnold, London - New York Sydney - Auckland.

\section{Metapragmatic reflections on text organisation in science texts}

The study interprets technical texts as specialized texts of science, with an emphasis on knowledge building and the way it is based on a combination of cognitive semantics and pragmatics. It also discusses ways in which knowledge is shared, a process essentially characterised by a reflexive attitude to sharing. It prioritises the metacomponent of texts that can be considered metadiscourses and examines the possibilities of metapragmatic reflections based on their direction. Among all these options, it focuses on the ones that help to organize the text. Qualitative analysis is offered of the language tools that implement the operation of discourse deixis and the functioning of discourse markers.

Keywords: texts of science, metadiscourse, metapragmatic reflections for text organization, discourse deixis, discourse markers.

CSONTOS NÓRA

Károli Gáspár Református Egyetem 